\title{
Sarcopenia és életminóség: a Sarcopenia Quality of Life (SarQoL) kérdőív hiteles magyar fordítása
}

\author{
Hodinka László dr. ${ }^{1}$ - Vereckei Edit dr. ${ }^{1}$. Gasparik Andrea Ildikó dr. ${ }^{2}$ \\ ${ }^{1}$ Országos Reumatológiai és Fizioterápiás Intézet, Budapest \\ ${ }^{2}$ Marosvásárhelyi Orvosi és Gyógyszerészeti Egyetem, Marosvásárhely (Târgu Mureș, Románia)
}

\begin{abstract}
Bevezetés: A sarcopenia, vagy időskori izomerő- és izomtömeg-csökkenés, napjaink komoly népegészségtani problémája. A betegséggel járó csökkent fizikai teljesítóképesség miatt az érintettek életminősége bizonyíthatóan romlik. Az általános életminőséget mérő skálák, mint a Rand Corporation Short Form 36 (SF-36) vagy a European Quality of Life (EuroQoL-5D) kérdőív nem mérik, és így nem mutatják ki a sarcopenia - életminőségre kifejtett - speciális hatását. A Sarcopenia Quality of Life (SarQoL - sarcopenia és életminőség) az első kimondottan erre a betegségre vonatkozó kérdőív, amelyet nemrég abból a célból fejlesztettek ki, hogy átfogó képet nyújtson a 65 évesnél idősebb sarcopeniás személyek életminőségéról.

Célkitüzés: Az eredeti SarQoL kérdốv magyar nyelvú, érvényes változatának kifejlesztése volt a célunk, annak fordítása, kultúrközi adaptációja és magyar nyelvi validálása révén.

Módszer: A fordításhoz az ajánlott nemzetközi protokollt követtük, ennek öt lépése: két külön magyar fordítás, a két változat szintézise, visszafordítása angol nyelvre, az eredeti és a visszafordított változatok szakértối csoport általi öszszevetése, előtesztelés. A magyar nyersfordítást 20 különböző iskolázottságú és társadalmi hátterú vizsgált személy (10 klinikailag sarcopeniásként kórismézett és 10 nem sarcopeniás) töltötte ki. Minden személynél felmértük a kérdések érthetőségét, a válaszadáskor adódó esetleges nehézségeket.

Eredmények: Az eredeti kérdőív szerzői által a fordításhoz előírt módszertan elvárásai szerint a végső változat az eredetivel mind tartalmilag, mind pontosságában megegyezett. A SarQoL kérdőivet kifejlesztő munkacsoport a magyar változatot közérthetőnek, feladatára alkalmasnak, hitelesnek találta.

Köpetkeztetés: A klinikai jellemzők alapján kórismézett sarcopeniás személyek által kitöltött kérdőív a hazai tartalmi hitelesítést követően hasznos és szükséges életminőség-értékelő eszközként áll majd a sarcopeniás magyar betegek rendelkezésére.
\end{abstract}

Orv Hetil. 2018; 159(36): 1483-1486.

Kulcsszavak: sarcopenia, életminőség, kérdőíi, SarQoL

\section{Sarcopenia and quality of life: the validated Hungarian translation of the Sarcopenia Quality of Life (SarQoL) questionnaire}

Introduction: Sarcopenia, or age-related muscle loss, is emerging as a serious public health concern. Due to the impaired physical performance associated with sarcopenia, a reduced quality of life (QoL) has been evidenced in the affected individuals. Generic instruments, such as Rand Corporation Short Form 36 (SF-36) or the European Quality of Life (EuroQoL-5D) questionnaires do not accurately assess the impact of sarcopenia on QoL. SarQoL (Sarcopenia Quality of Life) questionnaire, was the first disease-specific questionnaire addressing the quality of life in patients with sarcopenia and has been recently designed for providing a global assessment of the quality of life in community-dwelling elderly subjects aged 65 years and older.

Aim: Our aim was the development of a valid Hungarian version of the original SarQoL, through the translation, cultural adaptation and content validation of the original questionnaire.

Method: We followed the recommended process, the international protocol of translation in five steps: two initial translations, synthesis of the two translations, backward translation, expert committee to compare translations with the original questionnaire and pretest. The pretest process involved 20 subjects ( 10 clinically sarcopenic and 10 nonsarcopenic with different educational and socioeconomic backgrounds) who were asked to complete the question- 
naire. Feedbacks were requested from all subjects regarding the comprehensibility of questions or difficulties in completing the test.

Results: Using the recommended best practice protocol for translation, the pre-final version is comparable with the original instrument in terms of content and accuracy.

Conclusion: After the content validation with clinically sarcopenic persons it should be a useful tool to assess the quality of life of people with sarcopenia among elderly Hungarian patients.

Keywords: sarcopenia, quality of life, questionnaire, SarQoL

Hodinka L, Vereckei E, Gasparik AI. [Sarcopenia and quality of life: the validated Hungarian translation of the Sarcopenia Quality of Life (SarQoL) questionnaire]. Orv Hetil. 2018; 159(36): 1483-1486.

(Beérkezett: 2018. április 14.; elfogadva: 2018. május 15.)

\section{Rövidítések}

$\mathrm{CT}=($ computer tomography) számítógépes tomográfia; $\mathrm{DEXA}=($ dual energy X-ray absorptiometry) kettős energiájú röntgensugár-elnyelődés mérése; EuroQoL-5D, EQ-5D = az Európai Életminőség Kérdőív 5 kérdéses változata; EWGSOP $=$ (European Working Group on Sarcopenia in Older People) európai munkacsoport az időskorúak sarcopeniájának meghatározására; HRQoL = (Health Related Quality of Life) az egészségi állapottal kapcsolatos életminőség; $M R$ = mágneses rezonancia; SarQoL $=($ Sarcopenia Quality of Life $)$ a sarcopenia által érintettek életminősége; SF-36 = a Rand Corporation Short Form kérdőívének 36 kérdéses változata

A sarcopenia, vagy időskori izomerő- és izomtömegcsökkenés, napjaink demográfiai változásaira is visszavezethetően igen komoly népegészségtani problémát jelent. A kor elörehaladtával az izomszövet fokozatosan leépül, a folyamat következményeként pedig csökken az izom tömege és ereje. Ezt az állapotot nevezzük sarcopeniának [1]. Bebizonyosodott, hogy ezeknél az egyéneknél az egészségi állapottal kapcsolatos életminőség (Health Related Quality of Life, HRQoL) fokozatosan romlik. A sarcopenia és az életminőség összefüggéseit felmérő kutatás nagy részét korábban olyan általános eszközökkel végezték, mint például a Short Form 36 (SF-36) és az EuroQoL (EQ)-5D életminőség-mérő skála, amelyek valószínúleg nem eléggé érzékenyek a sarcopenia életminőségre gyakorolt hatásának értékelésére, ezért szükség volt egy speciális eszköz kifejlesztésére [2].

A SarQoL (Sarcopenia Quality of Life - sarcopenia és életminőség) volt az első betegségspecifikus kérdőív, mely a sarcopeniás betegek életminőségével foglalkozik, és amelyet azért fejlesztettek ki, hogy átfogó képet kapjunk a 65 évesnél idősebb, közösségben élő személyek életminőségéről. Eredetileg francia nyelven készült, egy évvel később angol, majd román nyelvre is lefordították és validálták [3-5].

Célunk az eredeti SarQoL magyar nyelvű változatának kifejlesztése, kulturális adaptációja és nyelvi validálása volt, hogy végül egy olyan megbízható eszközhöz jussunk, amellyel az itthoni és a határokon túli, sarcopeniá- ban szenvedő magyar páciensek életminősége is felmérhető.

$\mathrm{Az}$ eredeti SarQoL olyan többdimenziós kérdőív, amely 22 kérdésbe foglal 55 , a vizsgált személy által választott, magára érvényesnek tartott információt, amelyek kérdésenként egy-egy négypontos Likert-skála szerint értékelhetők. A 22 kérdés a várhatóan diszfunkciós területeknek megfelelően (testi és lelki egészség, mozgásszervi zavarok, testfelépítés, életmúködések, mindennapi tevékenységek, szabadidős tevékenységek és félelmek) hét fejezetben jelennek meg [3].

\section{Módszer}

Az eredeti kérdőiv fejlesztối csoportja által meghatározott eljárást, azaz a fordítás nemzetközi protokollját követtük. Az első fázisban az angol változatot két magyar anyanyelvű fordító (orvos és nyelvtanár) egymástól függetlenül fordította magyarra. Minthogy a magyar változatot határon túli alkalmazásra is szánjuk, a nem orvos fordítónak Románia magyar nyelvű területén született és ott dolgozó angol szakos tanárt kértünk fel. A második, egyeztetési fázisban a fordítók kicserélték és véleményezték egymás fordítását. Megállapították, hogy a fordítások az eredeti koncepciójuknak megfelelően születtek meg. Néhány kifejezésben voltak nyelvhasználati szintű eltérések, ezekben is gyakorlatilag azonos kifejezéseket, szinonimákat alkalmaztak. Téves szövegértés, eltérő értelmezésre vezetô eltérés nem volt. A kölcsönösen elfogadott, egyeztetett változat került a következő, visszafordítási fázisba. Két, angol nyelvterületen született és iskolázott, illetve évtizedek óta ott élő személy egymástól függetlenül, az angol szöveg ismerete nélkül fordította a magyar verziót angolra. A két fordítás elkészülte után egyeztette a négy fordító az angol változatokat. Megállapították, hogy mindkét visszafordító törekedett a magyar kifejezések pontos visszaadására, így fordításaik szinte szóról szóra megegyeztek. A fordítási protokoll ezután szakértői bizottság általi értékelést ír elő. A fordítókon kívül betegoktató, magatartás-kutató, irodalomtörténész és betegegyesületi vezető minősítette a magyar változatot. 
Néhány nyelvhelyességi változtatást, árnyaltabb megfogalmazást javasoltak, és hozzájárultak a szöveg vizsgálati személyeken történő ellenőrzéséhez. A fordítók és a szakértők által több lépésben egyeztetett nyersfordítást tíz klinikailag sarcopeniásnak minősített beteg és tíz illesztett, vélhetően nem sarcopeniás, különféle iskolázottságú és társadalmi-gazdasági háttérrel rendelkező egyén közremúködésével értékeltük. A kérdőív kitöltése kapcsán betartottuk az érzékeny adatok kezelésére vonatkozó jogszabályi előírásokat. Az egészségi állapotukra vonatkozó adataikat nem kértük és nem kezeltük, a kérdésekre adott válaszaikat e tekintetben nem értékeltük. A kérdések érthetőségére vonatkozóan kértük véleményüket. Erről tájékoztattuk őket, aminek alapján a kérdőív értékelését önként vállalták. A vizsgált személyek fele az egyik fordító és szakértő jelenlétében töltötte ki a kérdőívet, hogy közvetlenül állapíthassuk meg az esetleges értelmezési nehézségeket. Minden vizsgált személytől írásbeli visszajelzést kértünk a kérdések világos voltáról, a teszt kitöltésekor adódó problémákról. Felmérésünk és a visszajelzések nyomán - a szó szerinti és a fogalmi ekvivalencia érdekében - két kérdést módosítottunk, amivel a bizottság többi tagja is egyetértett.

\section{Eredmények}

Az első, speciálisan sarcopeniára kifejlesztett, életminőséget értékelő, eredeti SarQoL kérdőív magyar nyelvre fordított, adaptált és elővalidált változatát különösebb nehézség nélkül hoztuk létre. A fordításhoz az ajánlott nemzetközi módszertant követve mind a tartalom, mind a hitelesség és pontosság tekintetében megbízható változatot kaptunk. A kérdőív a tartalmi hitelesítése után (a sarcopenia fizikális és funkcionális jellemzőit mutató alanyok segítségével történő végső validálását követően) hasznos segítség lehet a sarcopeniában szenvedő magyar páciensek életminőségének felmérésében.

\section{Megbeszélés}

A sarcopenia jelensége először 1987-ben jelent meg a gerontológiai szakirodalomban. Számos leíró közlemény után 2003-ban történt az első kísérlet a komplex folyamat összegzésére és első meghatározására: a sarcopenia az izomtömeg, az izomerô és a funkcionális képességek egyidejü csökkenése [1].

Továbbra is vita folyt arról, hogy a sarcopenia meddig tekinthető a „fiziológiás” öregedés részének, milyen határérték átlépésekor válik betegséggé és funkcionális akadállyá. Ezért európai gerontológiai szakértőkből munkacsoport alakult (European Working Group on Sarcopenia in Older People, EWGSOP), amely konszenzust alakított ki a sarcopenia meghatározásáról és diagnózisáról: a sarcopenia az izomtömeg csökkenése, amely az izomerő és/vagy a fizikai teljesítőképesség csökkenésével társul [6]. A sarcopenia kialakulásában számos genetikai, biokémiai, hormonális mechanizmus játszhat szerepet, az izomzat involúciója, amely a csontremodelling megbomlásával, a porc felépítés-lebontás egyensúlyának eltolódásával analóg folyamat. Szélesebb kontextusban az életkorral növekvő esendőség egyik komponense [7-9]. A sarcopenia és az osteoporosis patomechanizmusa lényegileg egyezik: az izomtömeg és a csonttömeg fogyását a zsírszövet felszaporodása kíséri (sarcopeniás obesitas), az izomtömeg és -erő csökkenése növeli az elesésből származó osteoporoticus csonttörés veszélyét. A törési kockázat funkcionális oldalról kapcsolja össze az osteoporosist és a sarcopeniát. Ennek alapján vetődött fel, hogy a sarcopenia a mozgászavar-szindróma (dysmobility syndrome) részeként önálló kockázati tényezője az időskori csonttörésnek $[10,11]$.

A sarcopeniás személyek korai azonosítása a jelenség komoly kockázatai miatt fontos. Öt, a vizsgáltak életkorától függetlenül alapvetően a fizikai teljesítőképességen alapuló kérdéseket és teszteket alkalmazó szürőmódszer áll rendelkezésre. Ezek a sarcopenia meghatározásán alapuló indikátorokat tartalmaznak (járásidő, egyszerű mozgások, szorítóerő, elesések gyakorisága [12]). Egyszerűsége mellett validált vágáspontot tartalmaz a SARCF kérdőív, fordításunk ellenőrzésekor erre támaszkodtunk [7]. A sarcopenia kórismézésére több, egymást kiegészítő módszer áll rendelkezésre. Az izomtömeg meghatározása klinikai célra a legegyszerúbben antropometriai adatok alapján és a bioelektromos ellenállás mérésével, tudományos célra az erre a célra fejlesztett programok segítségével kettős energiájú röntgensugár-abszorpciós (DEXA) módszerrel, valamint korszerú képalkotó eljárásokkal (CT, MR, ultrahang) történhet. Az izomerő a szorító- és nyomóerők mérésével határozható meg. A fizikai teljesítőképességet meghatározott mozgások kivitelezéséhez szükséges időkkel, meghatározott mozgások kivitelezésének képességével és ezek kombinációjával mérik [13].

A sarcopenia gyakoriságát a leírt módszerekkel történő keresztmetszeti populációs vizsgálatokban határozták meg. Kilenc ország 18 363, 65 évesnél idősebb személyét vizsgálták: a sarcopenia prevalenciája 12,6 és 17,5 között volt [14]. Belgiumban 288, 80 éves vagy idősebb személy körében az EWGSOP-kritériumokra alapozott sarcopenia gyakoriságát 12,5\%-nak találták [15]. Magyar szerzők 205, 60 évesnél idősebb, idősotthonban gondozott járóképes személy között szintén az EWGSOP-kritériumokon alapuló klinikai módszerekkel 73 esetben $(35,6 \%)$ állapítottak meg sarcopeniát. Ez kiugróan magas érték, az indiai prevalenciának felel meg. Vizsgálták a funkcionális mobilitást, a fehérjebevitelt, a fizikai aktivitást, társbetegségek jelenlétét és a dohányzást. A sarcopenia megjelenése összefüggött a csökkent mobilitással, a kevesebb korábbi fizikai tevékenységgel, a multimorbiditással és a dohányzással, azonban a fehérjebevitellel nem [16]. A magas mért prevalencia valószínúleg annak tulajdonítható, hogy az idősotthonba kerülés szelektálja a sarcopenia kockázati tényezőivel eleve rendelkező személyeket. A sarcopenia nem csupán a fizikai 
teljesítőképesség romlásával jár. A kognitív képességek csökkenése és klinikai depresszió kíséri [17, 18].

A sarcopenia az érintettek, gondozóik és a társadalom számára jelentős veszélyeket hordoz, és jelentős betegségterhet képvisel. Kezelési módszereinek hatásossága kevéssé bizonyított. Megelőzése, járulékos kockázatainak kivédése, az állapot javítása a rendszeres testmozgástól, célzott erôsító és egyensúlyjavító gyakorlatok rendszeres végzésétől várható. A betegségterhek teljes körú bemutatásához és a beavatkozások hatásának méréséhez járul hozzá az életminőség követése. Hangsúlyozzuk, hogy a SarQoL kérdőív - amelynek magyar változatát a fejlesztőbizottság elfogadta - nem használható szürésre vagy az állapot kórismézésére [2]. A magyar kérdőív a sarcopenia tudományos vizsgálatát és klinikai követését segíti hazánkban. Szabadon letölthető a http://www. sarqol.org./sites/sarqol/files/Questionnaire_SarQoLHU-2017-06_0.pdf internetes honlapról, és a klinikai módszerekkel igazolt sarcopeniások életminőségének vizsgálatára az adatvédelmi szabályok betartásával használható. A sarcopenia jelenségének, a szűrési és diagnosztikai lehetőségeknek a szélesebb körü ismerete és elterjedése vezethet az általa érintett betegek minél korábbi felismeréséhez, mozgásprogramjaik beindításához és - ily módon - életminőségük mérhető javulásához.

Anyagi támogatás: A közlemény megírása anyagi támogatásban nem részesült.

Szerzôi munkamegosztás: H. L.: A munka megszervezése, a záró jegyzőkönyv elkészítése. V. E.: A munka tárgyát képező kérdőív magyar szövege érthetőségének ellenőrzése, a bevont személyek megjegyzéseinek értékelése. G. A. I.: A munka tárgyát képező fordítás módszertani irányítása és orvosszakmai ellenőrzése az eredeti angol és a román nyelvű fordításokkal történő összevetéssel. A cikk végleges változatát mindhárom szerző elolvasta és jóváhagyta.

Érdekeltségek: A szerzőknek nincsenek érdekeltségeik.

\section{Irodalom}

[1] Marcell TJ. Sarcopenia: causes, consequences, and preventions. J Gerontol A Biol Sci Med Sci. 2003; 58: M911-M916.

[2] Beaudart C, Reginster JY, Geerinck A, et al. Current review of the SarQoL ${ }^{\oplus}$ : a health-related quality of life questionnaire specific to sarcopenia. Expert Rev Pharmacoecon Outcomes Res. 2017; 17: 335-341

[3] Beaudart C, Biver E, Reginster JY, et al. Development of a selfadministrated quality of life questionnaire for sarcopenia in elderly subjects: the SarQoL. Age Aging 2015; 44: 960-966.
[4] Beaudart C, Edwards M, Moss C, et al. English translation and

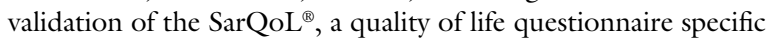
for sarcopenia. Age Ageing 2017; 46: 271-276.

[5] Gasparik AI, Mihai G, Beaudart C, et al. Psychometric performance of the Romanian version of the SarQoL ${ }^{\circledR}$, a health-related quality of life questionnaire for sarcopenia. Arch Osteoporos. 2017; 12: 103.

[6] Cruz-Jentoft AJ, Baeyens JP, Bauer JM, et al. Sarcopenia: European consensus on definition and diagnosis: Report of the European Working Group on Sarcopenia in Older People. Age Ageing 2010; 39: 412-423.

[7] Malmstrom TK, Miller DK, Simonsick EM, et al. SARC-F: a symptom score to predict persons with sarcopenia at risk for poor functional outcomes. J Cachexia Sarcopenia Muscle 2016; 7: 28-36.

[8] Calvani R, Marini F, Cesari M, et al. Biomarkers for physical frailty and sarcopenia: state of the science and future developments. J Cachexia Sarcopenia Muscle 2015; 6: 278-286.

[9] Fougére B, Vellas B, van Kan GA, et al. Identification of biological markers for better characterization of older subjects with physical frailty and sarcopenia. Transl Neurosci. 2015; 6: 103110.

[10] Binkley N, Krueger D, Buehring B. What's in a name revisited: should osteoporosis and sarcopenia be considered components of "dysmobility syndrome"? Osteoporos Int. 2013; 24: 29552959.

[11] Hill KD, Farrier K, Russell M, et al. Dysmobility syndrome: current perspectives. Clin Interv Aging 2017; 12: 145-152.

[12] Yu SC, Khow KS, Jadczak AD, et al. Clinical screening tools for sarcopenia and its management. Curr Gerontol Geriatr Res. 2016; 2016: 5978523.

[13] Beaudart C, McCloskey E, Bruyére O, et al. Sarcopenia in daily practice: assessment and management. BMC Geriatr. 2016; 16: 170.

[14] Tyrovolas S, Koyanagi A, Olaya B, et al. Factors associated with skeletal muscle mass, sarcopenia, and sarcopenic obesity in older adults: a multi-continent study. J Cachexia Sarcopenia Muscle 2016: 7: 312-321.

[15] Legrand D, Vaes B, Matheï C, et al. The prevalence of sarcopenia in very old individuals according to the European consensus definition: insights from the BELFRAIL study. Age Ageing 2013; 42: 727-734.

[16] Kovács É, Jónásné Sztruhár I, Asiama E, et al. Prevalence and associated factors of sarcopenia among older adults living in institutions providing long-term care. [A sarcopenia prevalenciája, valamint az egészség- és életmódbeli tényezőkkel való kapcsolata a tartós ellátást nyújtó intézményekben élő idősek körében.] Orv Hetil. 2016; 157: 1847-1853. [Hungarian]

[17] Tolea MI, Galvin JE. Sarcopenia and impairment in cognitive and physical performance. Clin Interv Aging 2015; 10: 663671.

[18] Hamer M, Batty GD, Kivimaki M. Sarcopenic obesity and risk of new onset depressive symptoms in older adults: English longitudinal study of ageing. Int J Obes. 2015; 39: 1717-1720.

(Gasparik Andrea Ildikó dr., e-mail: ildikogasparik@gmail.com) 